\title{
Effect of beta 1,3 glucan in stress responses of the pencilfish (Nannostomus trifasciatus) during transport within the rio Negro basin
}

\author{
Janessa S. Abreu ${ }^{1}$, Richard P. Brinn², Levy C. Gomes ${ }^{3}$, Dawn Michelle McComb ${ }^{4}$, \\ Bernardo Baldisserotto ${ }^{5}$, Sérgio F. Zaiden ${ }^{6}$, Elisabeth C. Urbinati ${ }^{7}$ and Jaydione L. Marcon ${ }^{8}$
}

We investigated the use of beta 1,3 glucan as an imunostimulant during a transport experiment to determine the effects upon the stress response of the pencilfish (Nannostomus trifasciatus). Pencilfish were fed for seven days with different concentrations of beta 1,3 glucan: $0.0 \%$ (control); $0.01 \% ; 0.1 \%$ and $0.5 \%$ of beta 1,3 glucan per $\mathrm{kg}_{\text {of feed }}{ }^{-1}$. Fish were then transported for 24 hours by boat from Barcelos to Manaus. The highest dose of beta 1,3 glucan in the food increased $\mathrm{Na}^{+}$influx after 12 hours of transport and 0.1 and $0.5 \%$ beta 1,3 glucan maintained the flux of both ions close to zero at 24 hours. All doses of beta 1,3 glucan reduced $\mathrm{K}^{+}$loss significantly in the beginning of the transport, but after 12 to 24 hours did not. No significant differences in whole body cortisol or survival were observed. Our results indicate that pencilfish had ionic alterations during transport from Barcelos to Manaus. The lack of significant differences in whole body cortisol and survival rate in addition to the maintenance of $\mathrm{Na}^{+}$and $\mathrm{K}^{+}$balance during transport reinforce the positive effects of beta 1,3 glucan immunostimulant on fish homeostasis. Therefore, we recommend its addition to food prior to transport.

O objetivo deste trabalho foi verificar se o imunoestimulante beta 1,3 glicano, adicionado à ração fornecida dias antes do transporte, pode minimizar algumas respostas de estresse do peixe lápis (Nannostomus trifasciatus) capturado na natureza. Estes peixes foram alimentados por sete dias com diferentes concentrações de beta 1,3 glicano: $0,0 \%$ (controle); $0,01 \%$; $0,1 \%$ e $0,5 \%$ de beta 1,3 glicano.kg de ração $0^{-1}$. Após este período, as caçapas foram transportadas via barco de Barcelos para Manaus, com duração de 24 horas. Nos peixes alimentados com a maior concentração de beta 1,3 glicano na ração foi verificado aumento no influxo de $\mathrm{Na}^{+}$após 12 horas de transporte e nos peixes alimentados com 0,1 e $0,5 \%$ de beta 1,3 glicano, o fluxo destes íons foi mantido próximo de zero no final de 24 horas de transporte. Todas as doses de beta 1,3 glicano reduziram significativamente a perda de $\mathrm{K}^{+}$no início do transporte, mas, após 12 horas até o final do transporte houve efeito significativo no efluxo de $\mathrm{K}^{+}$. Não foram verificadas diferenças significativas entre tratamentos ou tempos de amostragem para os níveis de cortisol corpóreo. A taxa de sobrevivência não diferiu ao final do experimento. Nossos resultados indicam que o transporte entre Barcelos e Manaus promoveu alterações iônicas no peixe-lápis e a ausência de diferenças significativas no cortisol corpóreo e na taxa de sobrevivência aliada, à manutenção do equilíbrio de sódio e potássio durante o transporte, reforça o efeito positivo do imunoestimulante beta 1,3 glicano na homeostase dos peixes e sua adição à ração é recomendada.

Key words: Cortisol, Immunostimulant, Ion fluxes, Ornamental fish, Rio Negro basin.

\section{Introduction}

The Brazilian marine and fresh water ornamental fishes industry depends largely on their natural fish stocks and the Amazon basin is the main source of freshwater species
(Anjos et al., 2009). In 2009, the exporting of ornamental fishes brought a $4 \%$ increase in Brazil's GDP totaling seven million USD. Even though there was a decrease of $26 \%$ in volume between 2008 and 2009 there was a $25 \%$ increase in profit (Brasil, 2009).

\footnotetext{
${ }^{1}$ Universidade Federal de Mato Grosso, Faculdade de Agronomia, Med. Veterinária e Zootecnia (FAMEVZ) - Zootecnia e Extensão Rural. Av. Fernando Corrêa da Costa, nº 2.367, Boa Esperança, 78060900 Cuiabá, Mato Grosso, Brazil. janessabreu@yahoo.com.br ${ }^{2}$ Florida International University, Miami, Florida, United States. brinnr@fiu.edu ${ }^{3}$ Universidade Vila Velha, Vila Velha, Espírito Santo, Brazil. levy.gomes@uvv.br ${ }^{4}$ Ocean Classrooms, Boulder, Colorado, USA.mikki@oceanclassrooms.com ${ }^{5}$ Universidade Federal de Santa Maria, Santa Maria, Rio Grande do Sul, Brazil. bernardo@smail.ufsm.br ${ }^{6}$ Universidade de Rio Verde, Rio Verde, Goiás, Brazil. sfzaiden@hotmail.com ${ }^{7}$ Universidade Estadual Paulista, Jaboticabal, São Paulo, Brazil. bethurb@caunesp.unesp.br ${ }^{8}$ Universidade Federal do Amazonas, Manaus, Amazonas, Brazil. jlmarcon@ufam.edu.br
} 
The State of Amazonas exports more than 25 million fish annually, which represents $84 \%$ of the country's freshwater ornamental fishes (IBAMA, 2008). The sale of ornamental fish in this region is fundamental to the local economy, primarily within small fishing communities (Junk et al., 2007). The fishing efforts for freshwater ornamental fishes are strong in the rio Negro basin, in particular the region of Barcelos/ AM, $386 \mathrm{~km}$ upstream from Manaus (Chao et al., 2001). It is difficult to estimate how many people are involved with fishing in the region, but the Non Governmental Organization Project Piaba estimates about 1000 families living directly from ornamental fishes (IBAMA, 2008). The rio Negro basin has a great diversity of fishes (about 700 species) and more than 50 are used as ornamental (Prang, 2007). One of these species, the pencilfish (Nannostomus trifasciatus) is attractive and easy to market, representing about $5 \%$ of the total exported fishes (Anjos et al., 2007). Fishing for pencilfish is carried out in an artisanal manner developed from knowledge of native fishermen in the region, known as piabeiros. In the vicinity of Barcelos, the removal of this species occurs in different habitats such as streams, rivers, rapids, and lakes. With the use of simple fishing gear, the piabeiros capture the fish, which are packed in plastic boxes (totes) and transported in small boats to existing warehouses in Barcelos and, subsequently, to the distributors located in the city of Manaus. Boat transport between Barcelos and Manaus has a duration ranging from 24 to 30 hours. This step has been identified as one of the most critical processes of marketing within the Amazon region (Gomes et al., 2008).

If the fish are stressed at the beginning of the procedure, poor water quality and improper handling can cause increases in mortality rates during the export process (Waichman et al., 2001). Control of water quality during transportation can result in mortality rates around $5 \%$ on arrival, which is deemed acceptable by the export industry (Lim et al., 2003). Previous studies have demonstrated the addition of probiotic Efinol ${ }^{\circledR}$ $\mathrm{L}$ improved water quality during transport, decreasing the stress responses of marbled hatchetfish, Carnegiella strigata (Gomes et al., 2008) and reducing mortality of the cardinal tetra, Paracheirodon axelrodi (Gomes et al., 2009). However, in local cururu stingrays (Potamotrygon cf. hystrix) the use of probiotics and antibiotics in the water during transport did not reduce stress-related responses (Brinn et al., 2012).

While several sectors of the ornamental fish industry have adopted strategies to improve survival, little attention has been given to methods that result in increased stress resistance in fish, which would in turn, allow them to overcome the stressful conditions of transport (Lim et al., 2003). Therefore, it is of interest to determine the effectiveness of immunostimulants as stimulators of non-specific defense mechanisms in fish (Anderson, 1992; Sakai, 1999). This could lead to an increase in immune responses and provide protection against a variety of diseases. It is well known that the use of beta 1,3glucan raises innate immune responses in a variety of fishes (Santarém et al., 1997; Sakai, 1999; Bagni et al., 2005). However, there is little information about the effects of beta1,3 glucan on physiological stress responses in fish (Jeney et al., 1997; Kirchhoff et al., 2011; Chagas et al., 2012). Therefore, the goal of this study was to verify if supplementing beta 1,3 glucan, to the feed prior to transport, could minimize the stress responses of pencilfish (Nannostomus trifasciatus).

\section{Material and Methods}

This study was conducted in the middle rio Negro basin, near município de Barcelos, Amazonas State. Approximately 3,200 specimens of pencilfish (Nannostomus trifasciatus), with an average weight of $0.267 \pm 0.082$ grams, were captured by professional fishermen on the banks and submerged vegetation located along the lower course of the Pixurituba stream. The fish were randomly distributed in 16 plastic 40 liter totes containing only five liters of local stream water and stocked at a density of 40 individual fish per liter. This density is commonly used for this species by fishermen in the region during the maintenance process.

A reference diet in powder was formulated (Table 1) and the beta 1,3 glucan (Nutricell ${ }^{\circledR}$, Biorigin, São Paulo State, Brazil) was mixed to feed ingredients, constituting four treatments (with four repetitions per treatment): $0.0 \%$ (control); $0.01 \%$ (treatment 1 ); $0.1 \%$ (treatment 2 ) and $0.5 \%$ (treatment 3 ). Each treatment is representative of a percentage of beta 1,3 glucan per $\mathrm{Kg}$ of feed.

During the pre-transport period, water in boxes was exchanged twice and the fish fed ad libitum three times daily (9:00; 13:00 and 17:00 hours), with the experimental feeds. At the end of the 7-day feeding period, fish were fasted for 24 hours and transported for 24 hours via boat from Barcelos to Manaus under conditions in which fish are usually transported. The transport started at17:30 hours which is typical in the freshwater ornamental fishes industry. After transportation fish were maintained on the boat in their plastic totes used during the transport for recovery for another 24 hours. The water in the boxes was exchanged twice to avoid water quality loss during the recovery period.

The samples consisted of 40 fish captured for each treatment $(\mathrm{n}=40)$ which were quickly frozen in liquid nitrogen for determination of body cortisol. Samples were

Table 1. Diet reference ingredient composition (\%).

\begin{tabular}{lr}
\hline Composition analyzed & $\mathbf{\%}$ \\
\hline Dry matter & 85.52 \\
Crude protein & 32.05 \\
Ether extract & 6.97 \\
Crude fiber & 4.69 \\
Ash & 7.99 \\
Nitrogen free extract & 37.32 \\
Gross energy $\left(\mathrm{kcal}_{\mathrm{kg}} \mathrm{kg}^{-1}\right)$ & 4181.73 \\
\hline
\end{tabular}


Table 2. Water quality parameters before and after 24 hours of transportation of pencilfish ( $N$. trifasciatus) previously fed with different levels of beta 1,3 glucan. Mean \pm standard deviation. Same small letters indicate no differences among treatments (means of all sampling times are represented with the same value) and capital letters among samplings times (means of all treatments are represented with the same value).

\begin{tabular}{|c|c|c|c|c|c|c|c|}
\hline & & \multicolumn{6}{|c|}{ Water quality parameters } \\
\hline & & $\begin{array}{c}\text { Dissolved } \\
\text { oxygen } \\
\left(\mathrm{mg} . \mathrm{L}^{-1}\right)\end{array}$ & $\begin{array}{c}\text { Temperature } \\
\left({ }^{\circ} \mathrm{C}\right)\end{array}$ & pH (units) & $\begin{array}{c}\text { Conductivity } \\
\left(\mu \mathrm{S} . \mathrm{cm}^{-1}\right)\end{array}$ & 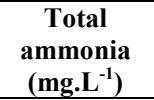 & $\begin{array}{c}\text { Unionized } \\
\text { ammonia } \\
\left(\mu \mathrm{g} . \mathrm{L}^{-1}\right)\end{array}$ \\
\hline \multirow{4}{*}{ Beta 1,3 glucan.kg food ${ }^{-1}$} & $0.0 \%$ & $2.42 \pm 1.05^{\mathrm{a}}$ & $28.58 \pm 1.43^{\mathrm{a}}$ & $6.45 \pm 0.15^{\mathrm{a}}$ & $22.01 \pm 4.53^{\mathrm{a}}$ & $1.02 \pm 0.44^{\mathrm{a}}$ & $2.20 \pm 1.60^{\mathrm{a}}$ \\
\hline & $0.01 \%$ & $2.05 \pm 0.67^{\mathrm{a}}$ & $28.89 \pm 1.01^{\mathrm{a}}$ & $6.46 \pm 0.15^{\mathrm{a}}$ & $20.34 \pm 3.54^{\mathrm{a}}$ & $1.05 \pm 0.30^{\mathrm{a}}$ & $2.40 \pm 1.20^{\mathrm{a}}$ \\
\hline & $0.1 \%$ & $2.42 \pm 1.19^{\mathrm{a}}$ & $28.55 \pm 1.25^{\mathrm{a}}$ & $6.45 \pm 0.19^{\mathrm{a}}$ & $20.98 \pm 4.06^{\mathrm{a}}$ & $1.16 \pm 0.40^{\mathrm{a}}$ & $2.80 \pm 2.20^{\mathrm{a}}$ \\
\hline & $0.5 \%$ & $2.46 \pm 1.04^{\mathrm{a}}$ & $28.64 \pm 1.01^{\mathrm{a}}$ & $6.35 \pm 0.11^{\mathrm{a}}$ & $17.94 \pm 2.78^{\mathrm{a}}$ & $0.89 \pm 0.21^{\mathrm{a}}$ & $1.60 \pm 0.70^{\mathrm{a}}$ \\
\hline \multirow{2}{*}{ Time of transport (h) } & 0 & $1.67 \pm 0.24^{\mathrm{B}}$ & $29.66 \pm 0.65^{\mathrm{A}}$ & $6.34 \pm 0.11^{\mathrm{B}}$ & $20.89 \pm 3.55^{\mathrm{A}}$ & $0.87 \pm 0.28^{\mathrm{B}}$ & $1.60 \pm 0.80^{\mathrm{B}}$ \\
\hline & 24 & $3.01 \pm 0.96^{\mathrm{A}}$ & $27.67 \pm 0.39^{\mathrm{B}}$ & $6.50 \pm 0.14^{\mathrm{A}}$ & $19.74 \pm 4.26^{\mathrm{A}}$ & $1.17 \pm 0.34^{\mathrm{A}}$ & $2.90 \pm 1.80^{\mathrm{A}}$ \\
\hline
\end{tabular}

taken at the beginning of transport (zero hour), at arrival and 24 hours after arrival. Before and after transport water temperature and dissolved oxygen were measured with YSI instruments (55 and 100) and with a digital conductivity meter (Bernauer, Blumenau, Santa Catarina State, Brazil). Measurements were performed directly in the water within the box. Total ammonia was determined by the salicylate method (Verdouw et al., 1978) and unionized ammonia calculated according to Emerson et al. (1975). Survival was determined at the end of transport.

Net $\mathrm{Na}^{+}$and $\mathrm{K}^{+}$fluxes were measured during 3, 12, and 24 hours of transport directly in a B462 flame photometer (Micronal, Brazil). Net ion fluxes (Jnet) were calculated based on changes in the ion concentration of water according to the equation by Gonzalez et al. (1998): Jnet $=(\mathrm{C} 1-\mathrm{C} 2) \mathrm{V}$. $(\mathrm{Mt})^{-1}$, where $\mathrm{C} 1$ and $\mathrm{C} 2$ are the bath ion concentration at the beginning and the end of the flux period, respectively, $\mathrm{V}$ is the bath volume in liters, $\mathrm{M}$ is the mass of the fish in $\mathrm{kg}$ and $t$ is the duration of the flux period in hours.

Whole-body cortisol was measured since it is virtually impossible to collect enough blood from this minute species of fish to measure plasma levels and extractions were performed according to de Jesus et al. (1991) with a few modifications. Briefly, pools of 10 fish were homogenized and a $0.5 \mathrm{~g}$ sample was taken for extraction. A triple extraction using diethyl ether and further radioimmunoassay were performed using a commercial kit (DPC ${ }^{\circledR}$, Diagnostic Products, Los Angeles, USA) for cortisol in humans. The assay was validated for the species by performing a parallelism test and calculating the extraction efficiency. The mean extraction efficiencies varied from $51 \%$ to $57 \%$, and the values reported are not corrected for efficiency.

Levene's test revealed that there was no homogeneity of variances for net ion fluxes and they were compared by the Scheirer-Ray-Hare extension of the Kruskal-Wallis test followed by the Nemenyi test. Differences between treatments and sampling times to body cortisol were compared using Kruskal-Wallis ANOVA on ranks $(\mathrm{P}<0.05)$. Water quality parameters were compared using a two-way ANOVA (time and treatment as variables) and the Tukey test using SAS software (version 8.0). The relationship between ammonia and conductivity was determined using linear regression. All other statistical tests were conducted using software STATISTICA (version 7.0). The data are expressed as mean $\pm \mathrm{SD}$ with the minimum significance level set at $\mathrm{p}<0.05$.

\section{Results}

Survival rates did not differ at the end of the experiment [(100.00 $\pm 0.51 \%$ (Control); $98.35 \pm 1.85 \%$ (0.01\%); $99.06 \pm$ $2.16 \%(0.1 \%)$ and $99.30 \pm 0.73 \%(0.5 \%)]$. Dissolved oxygen, $\mathrm{pH}$, total ammonia, and unionized ammonia did not differ between treatments, but were significantly higher after the transport compared to the initial condition. Temperature before transport decreased significantly upon arrival. Conductivity ranged from $20.89 \pm 3.55 \mu \mathrm{S} . \mathrm{cm}^{-1}$ before transport to 19.74 $\pm 4.26 \mu{\mathrm{S} . \mathrm{cm}^{-1}}^{-1}$ after transport, without significant differences among times and treatments (Table 2). Linear regression analysis showed linear positive correlation $\left(\mathrm{p}=0.0004 ; \mathrm{R}^{2}=\right.$ 0.968 ) between increased levels of total ammonia and water conductivity, after transporting (Fig. 1).

In the first 3 hours of transport, fish presented a large $\mathrm{Na}^{+}$ and $\mathrm{K}^{+}$loss, which reduced $\left(\mathrm{Na}^{+}\right)$or reverted to an influx $\left(\mathrm{K}^{+}\right)$ after 12 hours to the end of the transport. The highest dose of beta 1,3 glucan in the food increased $\mathrm{Na}^{+}$influx after 12 hours of transport and 0.1 and $0.5 \%$ beta 1,3 glucan maintained the flux of these ions close to zero at 24 hours. All doses of beta 1,3 glucan significantly reduced $\mathrm{K}^{+}$loss in the beginning of the transport, but after 12 hours to the end of transport did not (Fig. 2).

No significant differences were observed between treatments or sampling times for whole body cortisol levels (Fig. 3).

\section{Discussion}

Despite the importance of the ornamental fish trade in the Amazon region, studies that address the impacts of stress arising from the capture and transport process in Amazonian species is still very limited (Gomes et al., 2008, 2009; Brinn et al., 2012). 
Poor water quality during transport is a stressor, and can become a limiting factor (Emata, 2000). In all treatments at the beginning of transport, the average level of dissolved oxygen was $2.17 \mathrm{mg} . \mathrm{L}^{-1}$. The low oxygen content is due to the lack of aeration in the tanks maintained by the fishermen. After 24 hours, oxygen levels were higher $\left(3.01 \mathrm{mg} . \mathrm{L}^{-1}\right)$ as compared to the initial condition, coupled with significantly lower temperatures $\left(27.67^{\circ} \mathrm{C}\right)$. In the case of Amazonian fish, transport is carried out in open systems (totes) and exchange between air and water caused by boat movement, together with the mild temperature during the night, explains the higher levels of oxygen and lower temperature recorded at the end of the transport. In addition, oxygen concentrations observed during the experiment ( 2.17 to $3.01 \mathrm{mg} . \mathrm{L}^{-1}$ ) were not lethal to pencilfish, because it is a species found in regions where fluctuations in oxygen concentrations are common. Furthermore, fish of the Amazon have adapted to tolerate very low oxygen levels (less than $1 \mathrm{mg} \cdot \mathrm{L}^{-1}$ ) in their natural habitat for extended periods including anoxic events (Junk et al., 1983; Val, 1996; Muusze et al., 1998; Soares et al., 2006).

The $\mathrm{pH}$ and ammonia concentrations showed a profile similar to that of the dissolved oxygen, increasing after the transport as compared to the initial condition. Temperature along with $\mathrm{pH}$ can affect the production of toxic ammonia (Boyd \& Tucker, 1998). In the present study, the water $\mathrm{pH}$ increased from 6.34 (before transport) to 6.50 (after transport). This is in contrast with transports conducted in closed systems (plastic bags), in which a progressive decrease in $\mathrm{pH}$ occurs due to the accumulation of $\mathrm{CO}_{2}$ in the water. In this study, fish were transported in open air allowing for elimination of $\mathrm{CO}_{2}$ excreted by fish, resulting in $\mathrm{pH}$ increases. Despite the $\mathrm{pH}$ increase after pencilfish transport, $\mathrm{NH}_{3}$ levels were very low (1.60 to $2.90 \mu \mathrm{g}$. $\left.\mathrm{L}^{-1}\right)$. The positive correlation found between levels of total ammonia and conductivity can be explained by the fact that ammonia is the product of nitrogen excreted by fish and the accumulation of ammonium ions $\left(\mathrm{NH}_{4}^{+}\right)$

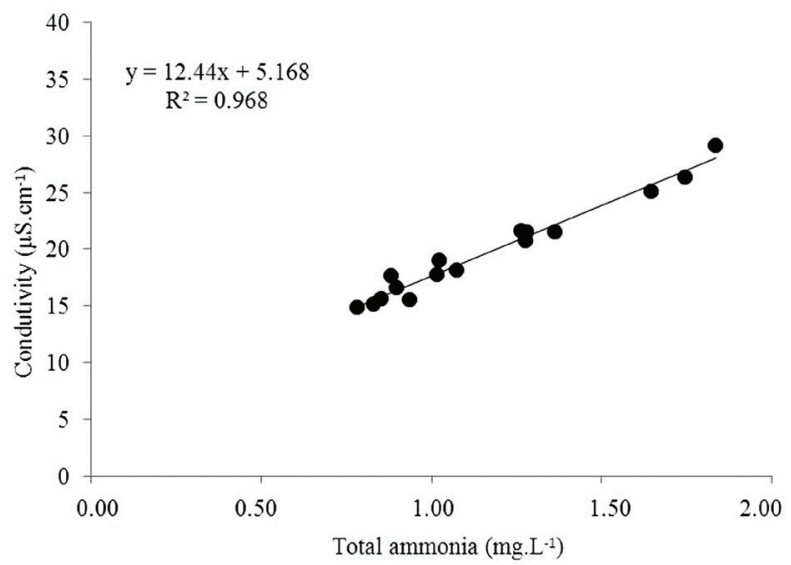

Fig. 1. Correlation between total ammonia $\left(\mathrm{mg} \cdot \mathrm{L}^{-1}\right)$ and conductivity $\left(\mu \mathrm{S} . \mathrm{cm}^{-1}\right)$ of water after transportation of pencilfish (Nannostomus trifasciatus) previously fed with different levels of beta 1,3 glucan. in the water helps raise conductivity.

In the present work, densities of pencilfish used during transport were similar to those used commercially and mortality observed after transport for 24 hours was less than $1 \%$ in all treatments. Waichman et al. (2001) suggested that one of the main reasons for ornamental fish mortality during transport from Barcelos to Manaus is the deterioration of water quality. However, water quality parameters in this study remained within a suitable range for this Amazonian species (Val, 1996), resulting in the low mortality. Similar results were found for the marbled hatchetfish (C. strigata) which were transported for 24 hours between municípios de Barcelos and Manaus, with reported mortality rates of less than $1 \%$, attributed to good water quality during the transport (Gomes et al., 2008).

The stress of transport triggers a series of physiological and biochemical changes. A primary response includes the release
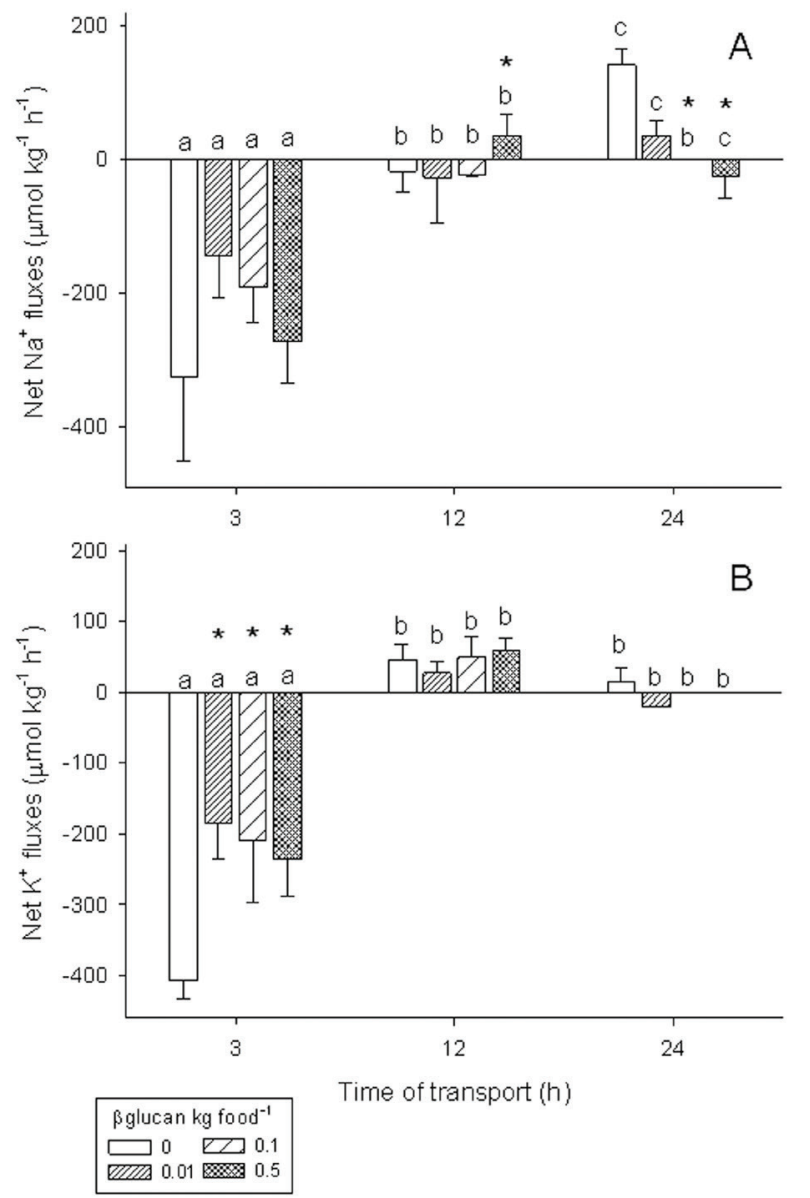

Fig. 2. $\mathrm{Net} \mathrm{Na}+(\mathrm{A})$ and $\mathrm{K}+(\mathrm{B})$ fluxes during transportation of pencilfish (Nannostomus trifasciatus) previously fed with different levels of beta 1,3glucan. Positive values indicate net influxes and negative values net effluxes. $\mathrm{N}=4$ boxes per treatment in each sample time. Different lower case letters indicate significant difference among times of transport within the same group and * indicate significant difference from control group within the same time of transport by Scheirer-Ray-Hare extension of the Kruskal-Wallis test followed by the Nemenyi test $(\mathrm{P}<0.05)$. 


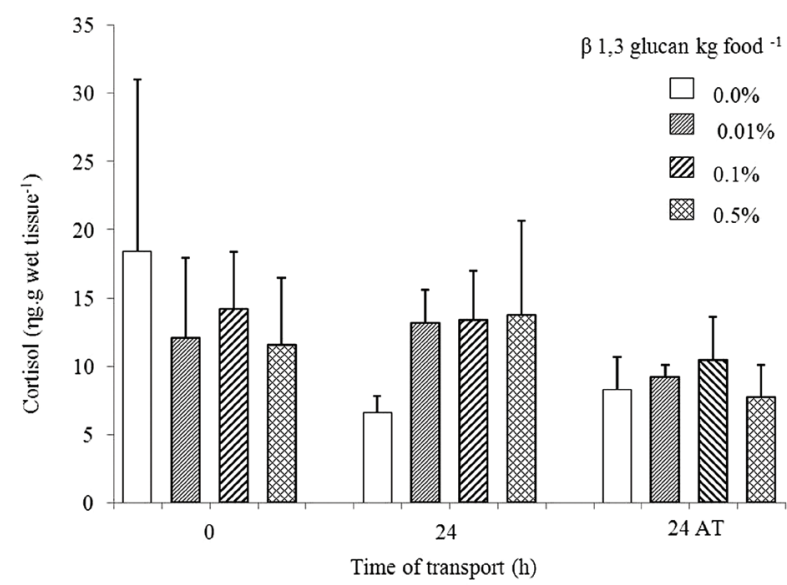

Fig. 3. Whole-body cortisol levels (mean \pm SD) during transportation of pencilfish (Nannostomus trifasciatus) previously fed with different levels of beta 1,3 glucan. No significant differences between all sampling times using the Kruskal-Wallis ANOVA on ranks were observed ( $\mathrm{P}>0.05) .0$ : initial time of transport; 24: 24 hours of transport; 24 AT: 24 hours after transport (recovery time).

of cortisol (Morgan \& Iwama, 1997), and secondary responses include changes in energy, metabolism and osmosis (Barton \& Iwama, 1991). The increase in cortisol levels in response to stress after shipping has been documented in several species of tropical fish (Carneiro \& Urbinati, 2001; Gomes et al., 2003; Urbinati et al., 2004; Fagundes \& Urbinati, 2008).

High cortisol levels lead to immunosuppression and the resulting exposure to pathogens can compromise health and increase fish mortality. The use of beta1,3 glucan is justified because other immunostimulant properties have been reported for a large number of fish species (Santarém et al., 1997; Sakai, 1999; Bagni et al., 2005), whose food supplements not only promote a significantly higher defense response against infectious agents (Anderson, 1992), and minimize the effects of stress. There are reports that rainbow trout (Oncorhynchus mykiss) showed lower concentrations of plasma cortisol after being supplemented with beta 1,3 glucan prior to a two hour transport (Jeney et al., 1997). In the present study, the pencilfish transported for 24 hours from Barcelos to Manaus did not show significant differences in body cortisol level. In an experiment using the same transport procedures, the marbled hatchetfish (C. strigata) had a fivefold increase in cortisol levels as compared to unstressed wild fish, with the highest concentrations at three hours into transport, which was double that of the initial condition (Gomes et al., 2008). Similar results were found for the cardinal tetra (P. axelrodi), whose cortisol levels during transport were approximately eight times greater as compared to basal levels, with the highest values being observed at 12 hours, demonstrating the species had high stress responses during this procedure (Gomes et al., 2009). In the present study, the pencilfish transported for 12 hours did not show significant differences in cortisol levels. The concentrations of beta 1,3 glucan tested, which ranged from 10.11 to $19.64 \eta \mathrm{g} . \mathrm{g}$ wet tissue $\mathrm{e}^{-1}$ at the beginning of the transport to 6.63 to $13.91 \eta \mathrm{g}$.g wet tissue $\mathrm{e}^{-1}$ on arrival did not differ significantly from those found 24 hours

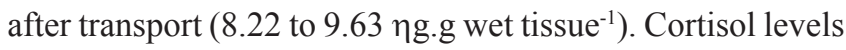
in this study are similar to basal values reported by Gomes et al. $(2008,2009)$ during the transport of marbled hatchetfish (C. strigata) (13.75 $\eta$ g.g wet tissue $\left.{ }^{-1}\right)$ and the Cardinal tetra $(P$. axelrodi) (7.82 ๆg.g wet tissue $\left.\mathrm{e}^{-1}\right)$, suggesting this species may respond more moderately to stress caused by this procedure.

Pencilfish showed a loss of $\mathrm{Na}^{+}$and $\mathrm{K}^{+}$at the beginning of the transport. Similar results were observed in the transport of cardinal tetra (Gomes et al., 2008) and marbled hatchetfish (Gomes et al., 2009). The addition of beta 1,3 glucan in the feed in all doses reduced the net loss of $\mathrm{K}^{+}$in the first 3 hours of transport and the highest dose significantly increased the net influx of $\mathrm{Na}^{+}$between 3 and 12 hours. Therefore, the addition of 1,3 glucan in feed is recommended to improve the ionic balance of pencilfish during transport.

Our results indicate that pencilfish had ionic alterations during transport from Barcelos to Manaus and the lack of significant differences in whole body cortisol and survival rate in addition to the maintenance of $\mathrm{Na}^{+}$and $\mathrm{K}^{+}$balance during transport reinforce the positive effects of beta 1,3 glucan immunostimulant on fish homeostasis. Therefore, we recommend its addition to food prior to transport.

\section{Acknowledgments}

This work was supported by a grant from National Geographic Conservation Fund (No. C47-04) and from Conselho Nacional de Desenvolvimento Científico e Tecnológico - CNPq (process $n^{\circ}$. 408795/2006-9). Scientific expedition was previously authorized by the Ministério de Ciência e Tecnologia, Brazil (MCT/CNPq, process $n^{\circ}$. EXC 023/05 to J. L. Marcon) and by the Instituto Brasileiro do Meio Ambiente e dos Recursos Naturais Renováveis (process $n^{0}$. 098/2005 DIFAP/IBAMA-DF). The authors would like to thank Biorigin Brasil (Lençóis Paulista, SP, Brazil) for the donation of Nutricell ${ }^{\circledR}$. B. Baldisserotto, L. C. Gomes and J. L. Marcon are research fellowship recipients from $\mathrm{CNPq} / \mathrm{Brazil}$.

\section{Literature Cited}

Anderson, D.P. 1992. Immunostimulants, adjuvants, and vaccine carriers in fish: application to aquaculture. Annual Review of Fish Diseases, 2: 281-307.

Anjos, H. D. B., R. M. S. Amorim, J. A. Siqueira \& C. R. Anjos. 2009. Exportação de peixes ornamentais do Estado do Amazonas, bacia amazônica, Brasil. Boletim do Instituto de Pesca, 39: 259-274.

Anjos, H. D. B., J. A. Siqueira \& R. M. S. Amorim. 2007. Comércio de peixes ornamentais do Estado do Amazonas. Boletim da Sociedade Brasileira de Ictiologia, 87: 4-5. 
Bagni, M., N. Romano, M. G. Finoia, L. Abeli, G. Scapigliati, P. G. Tiscar, M. Sarti \& G. Marino. 2005. Short and long term effects of a dietary yeast beta 1,3-glucan (Macrogard) and alginic acid (Ergosan) preparation on immune response in sea bass (Dicentrarchus labrax). Fish \& Shellfish Immunology, 18: 311-325.

Barton, B. A. \& G. K. Iwama. 1991. Physiological changes in fish from stress in aquaculture with emphasis on the response and effects of corticosteroids. Annual Review of Fish Diseases, 1: 3-26.

BRASIL, Ministério da Pesca e Aquicultura. Boletim Estatístico da Pesca e Aquicultura, 2008-2009. 2010. Available from: http://www. mpa.gov.br/images/Docs/Publicidade/anu \%C3\%A1rio\%20da $\% 20$ pesca\%20completo2.pdf. (24 Mar 2013).

Boyd, C. E. \& C. S. Tucker. 1998. Ecology of Aquaculture Ponds. Pp. 8-86. In: Boyd, C. E. \& C. S. Tucker (Eds.). Pond Aquaculture Water Quality Management. Boston, Massachusetts, Kluwer Academic Publishers.

Brinn, R. P., J. L. Marcon, D. M. McComb, L. C. Gomes, J. S. Abreu \& B. Baldisseroto. 2012. Stress responses of the endemic freshwater cururu stingray (Potamotrygon cf. histrix) during transportation in the Amazon region of the Rio Negro. Comparative Biochemistry and Physiology, Part A. 162: 139-145.

Carneiro, P. C. F. \& E. C. Urbinati. 2001. Salt as a stress response mitigator of matrinxã Brycon cephalus (Teleostei: Characoidei) during transport. Aquaculture Research, 32: 1-8.

Chagas, E. C., L. D. Araújo, C. H. Boijink, L. A. Inoue, L. C. Gomes \& F. R. Moraes. 2012. Respostas de tambaquis ao estresse por transporte após alimentação com dietas suplementadas com $\beta$-glucano. Biotemas, 25: 221-227.

Chao, N. L. 2001. Fisheries, diversity and conservation of ornamental fish of the Rio Negro River, Brazil- a review of Project Piaba (1989-99). Pp. 161-204. In: Chao, L. N., P. Petry, G. Prang, L. Sonneschein \& M. Tlusty (Eds.). Conservation and Management of Ornamental Fish Resources of the Rio Negro Basin, Amazonia, Brazil- Project Piaba. Manaus, University of Amazonas Press.

de Jesus, E. G., T. Hirano \& Y. Inui. 1991. Changes in cortisol and thyroid hormone concentrations during early development and metamorphosis in the Japanese flounder, Paralichthys olivaceus. General and Comparative Endocrinology, 82: 369-376.

Emata, C. 2000. Live transport of pond-reared milkfish Chanos chanos broodstock. Journal of the World Aquaculture Society, 31: 279-282.

Emerson, K., R. C. Russo, R. E. Lund \& R. V. Thurston. 1975. Aqueous ammonia equilibrium calculations: effect of $\mathrm{pH}$ and temperature. Journal of the Fisheries Research Board of Canada, 32: 2379-2383.

Fagundes, M. \& E. C. Urbinati 2008. Stress in pintado (Pseudoplatystoma corruscans) during farming procedures. Aquaculture, 276: 112-119.

Gomes, L. C., C. A. R. M. Araujo-Lima, R. Roubach \& E. C. Urbinati. 2003. Avaliação dos efeitos da adição de sal e da densidade no transporte de tambaqui. Pesquisa Agropecuária Brasileira, 38: 283-290.

Gomes, L. C., R. P. Brinn, J. L. Marcon, L. A. Dantas, F. R. Brandão, J. S. Abreu, D. M. McComb \& B. Baldisserotto. 2008. Using Effinol ${ }^{\mathbb{R}} \mathrm{L}$ during transportation of marbled hatchet-fish, Carnegiella strigata (Günther). Aquaculture Research, 39: 1292-1298.

Gomes, L. C., R. P. Brinn, J. L. Marcon, L. A. Dantas, F. R. Brandão, J. S. Abreu, P. E. M. Lemos, D. M. McComb \& B. Baldisserotto. 2009. Benefits of using the probiotic Efinol ${ }^{\circledR} \mathrm{L}$ during transportation of cardinal tetra, Paracheirodon axelrodi (Schultz), in the Amazon. Aquaculture Research, 40: 157-165.

Gonzalez, R. J.,C. M. Wood, R. W. Wilson, M. L. Patrick, H. L. Bergman, A. Narahara \& A. L. Val. 1998. Effects of water $\mathrm{pH}$ and calcium concentration on ion balance in fish of the Rio Negro, Amazon. Physiological Zoology, 71: 15-22.
IBAMA, Instituto Brasileiro do Meio Ambiente e dos Recursos Naturais Renováveis. Diagnóstico geral das práticas de controle ligadas a exploração, captura, comercialização, exportação e uso de peixes para fins ornamentais e de aquariofilia, 2008. Available from: http://www.ibama.gov.br/phocadownload/ recursos_pesqueiros/diagnostico_completo.pdf. (24 Mar 2013).

Jeney, G., M. Galeotti, D. Volpatti, Z. Jeney \& D. Anderson. 1997. Prevention of stress in rainbow trout (Oncorhynchus mykiss) fed diets containing different doses of glucan. Aquaculture, 154: 1-15.

Junk, W. J., M. G. M. Soares \& P. B. Bayley. 2007. Freshwater fishes of the Amazon River basin: their biodiversity, fisheries, and habitats. Aquatic Ecosystem Health \& Management, 10: 153-173.

Junk, W. J., M. G. M. Soares \& F. M. Carvalho. 1983. Distribution on fish species in a lake of the Amazon River floodplain near Manaus (Lago Camaleao), with special reference to extreme oxygen conditions. Amazoniana 7: 397-431.

Kirchhoff, N. T., D. D’Antignana, M. J. Leef, C. J. Hayward, R. J. Wilkinson \& B. F. Nowak, B. F. 2011. Effects of immunostimulants on ranched southern blue fin tuna Thunnus maccoyii: immune response, health and performance. Journal of Fish Biology, 79: 331-355.

Lim, L. C., P. Dhert \& P. Sorgeloos. 2003. Recent developments and improvements in ornamental fish packaging systems for air transport. Aquaculture Research, 34: 923-935.

Morgan, J.D. \& G. K. Iwama. 1997. Measurement of stressed states in the field. Pp. 247-270. In: Iwama, G. K., A. D. Pickering, J. P. Summer, C. B.

Muusze, B., J. L. Marcon, G.V.D. Thillart \& V. Almeida-Val. 1998. Hypoxia tolerance of Amazon fish: Respirometry and energy metabolism of the cichlid Astronotus ocellatus. Comparative Biochemistry and Physiology, Parte A, 120: 151-156.

Prang, G. 2007. An industry analysis of the freshwater ornamental fishery with particular reference to the supply of Brazilian freshwater ornamentals to the uk market. UAKARI, 3: 7-51.

Sakai, M. 1999. Current research status of fish immunostimulants. Aquaculture, 172: 63-92.

Santarém, M., B. Novoa \& A. Figueras. 1997. Effects of $\beta$-glucan on the non-specific immune responses of turbot (Scophthalmus maximus L.). Fish \& Shellfish Immunology, 7: 429-437.

Soares, M. G. M., N. A. Menezes \& W. J. Junk. 2006. Adaptations of fish species to oxygen depletion in a central Amazonian floodplain lake. Hydrobiologia, 568: 353 -367.

Urbinati, E. C., J. S. Abreu, A. C. S., Camargo \& M. A. P. Landines. 2004. Loading and transport stress of juvenile matrinxã (Brycon cephalus, Characidae) at various densities. Aquaculture, 229: 389-400.

Val, A. L. 1996. Surviving low oxygen levels: lessons from fishes of the Amazon. Pp. 59-73. In: Val, A. L., V. M. F. Almeida-Val \& D. J. Randall (Eds.). Physiology and Biochemistry of the Fishes of the Amazon. Manaus, Editora INPA.

Verdouw, H., C. J. A. Vanechted \& E. M. J. Dekkers. 1978. Ammonia determination based on indophenol with sodium salicylate. Water Research, 12: 399-402.

Waichman, A.V., M. P. Silva \& J. L. Marcon. 2001. Water quality monitoring during commercialization of Amazonian ornamental fish. Pp. 279-299. In: Chao, N. L., P. Petry, G. Prang, L. Sonneschein \& M. Tlusty (Eds.). Conservation and Management of Ornamental Fish Resources of the Rio Negro Basin, Amazonia, Brazil - Projetc Piaba. Manaus, University of Amazonas Press.

Submitted August 3, 2013 Accepted February 3, 2014 by Adalberto Val Published September 30, 2014 